\title{
Persentase dan Kualitas Karkas Itik Cihateup-Alabio (CA) pada Umur Pemotongan yang Berbeda
}

\author{
Percentage and Carcass Quality of Cihateup-Alabio (CA) Duck in Different Slaughter Age \\ A. Putra ${ }^{1}$, Rukmiasih ${ }^{1}$, R.Afnan ${ }^{1}$ \\ ${ }^{1}$ Departemen Ilmu Produksi dan Teknologi Peternakan, Fakultas Peternakan, Institut Pertanian Bogor \\ Jln. Agatis, Kampus IPB Darmaga, Bogor16680 \\ Correspondence author : asihipb08@yahoo.com
}

\begin{abstract}
Low demand of duck meat is influenced by its quality. Generally, ducks slaughtered at 8 weeks have low carcass quality. Slaughter age is expected to influence carcass quality. Therefore, the study of carcass quality in different slaughter ages $(8,10$, and 12 weeks) is needed. This research used 32 males and 18 females cihateup-alabio (CA) ducks. Ducks were grouped by hatching period. The experiment design was randomized block factorial $(3 \times 2)$. Treatments were slaughter age and sex. Traits measured were slaughter weight, percentage of carcass and its parts, physical and sensory quality of duck carcass. The result showed that interaction of slaughter age and sex affect slaughter weight. The higher slaughter age resulted higher breast and abdominal fat percentage, but had smaller thigh percentage. Sex had no effect on carcass percentage and its parts. Higher slaughter age and male sex showed better phisycal carcass quality. Differences in slaughter age and sex had no effect on panelist preference. This research concluded that higher slaughter age produces better carcass percentage and quality.
\end{abstract}

\section{PENDAHULUAN}

Itik merupakan salah satu ternak yang digunakan untuk memenuhi kebutuhan protein hewani masyarakat Indonesia. Kontribusi itik sebagai penyedia daging nasional pada tahun 2011 masih termasuk sangat rendah, yaitu sebesar $1.10 \%$ dari total produksi daging nasional, jauh di bawah jenis unggas lainnya, terutama ayam ras pedaging yang mencapai 52.38\% (Ditjennak 2012). Hal ini disebabkan oleh sedikitnya populasi itik, rendahnya permintaan, dan rendahnya produksi itik lokal. Populasi itik pada tahun 2011 sebesar 43.4 juta ekor, atau hanya $2.69 \%$ populasi unggas di Indonesia. Permintaan terhadap daging itik yang rendah juga dipengaruhi oleh aroma amis yang ada pada daging karena kandungan asam lemak pada daging itik tersebut. Itik di Indonesia umumnya masih digunakan sebagai penghasil telur. Dua tahun terakhir terjadi peningkatan permintaan bukan hanya pada telur, tetapi juga pada daging itik. Oleh karena itu, diperlukan strategi untuk dapat meningkatkan produktivitas ternak itik, salah satunya dengan cara persilangan. Persilangan dilakukan untuk mendapatkan keturunan itik yang lebih baik dibandingkan tetuanya.

Matitaputty et al. (2011) telah berhasil menyilangkan itik cihateup yang berasal dari daerah Tasikmalaya dengan itikAlabioyang berasal dari Kalimantan Selatan dengan hasil persilangan yang memiliki efek heterosis. Keturunannya pada umur 8 minggu menunjukkan performa utama pada bobot potong, efisiensi penggunaan pakan, bobot karkas, dan kualitas daging (komposisi asam lemak, aroma) yang lebih baik, tetapi masih banyak terdapat bulu-bulu jarum sehingga kualitas karkasnya masih kurang baik. Berbagai penelitian menjelaskan bahwa kualitas karkas seekor ternak dipengaruhi oleh berbagai faktor, di antaranya jenis ternak, pakan, dan umur ternak. Pemotongan itik pada umur yang tepat diharapkan akan menghasilkan karkas dengan kualitas fisik dan sensori yang dapat diterima.

\section{MATERI DAN METODE}

Materi yang digunakan dalam penelitian ini yaitu itik Cihateup-Alabio (CA) sebanyak 50 ekor yang terdiri dari 32 ekor itik CA jantan dan 18 ekor itik CA betina. Itik CA diperoleh dari hasil persilangan itik jantan Cihateup dengan itik betina Alabio di Balai Penelitian Ternak Ciawi, Bogor dan telurnya ditetaskan di Laboratorium penetasan unit unggas Fakultas Peternakan IPB.

Peralatan yang digunakan dalam penelitian ini yaitu kandang itik dengan ukuran panjang 1.5 meter, lebar 1.5 meter dan tinggi pagar penyekat 0.7 meter dengan kepadatan kandang sebesar $0.15-0.20 \mathrm{~m}^{2} /$ ekor. Litter yang digunakan berupa sekam padi setinggi $\pm 5 \mathrm{~cm}$. Peralatan kandang yang digunakan yaitu tempat pakan berupa feeder tray berdiameter $\pm 38 \mathrm{~cm}$, dan tempat air minum dengan kapasitas 5 liter. Peralatan lain yang digunakan adalah timbangan digital, pisau, gunting, wadah, freezer, alat tulis, piring kecil, dan gelas. Plastik kecil, pisau, piring, gelas, alat tulis, serta form organoleptik digunakan untuk uji organoleptik.

Penelitian ini diawali dengan persiapan kandang dan peralatan. Pembersihan kandang menggunakan sabun, desinfektan dan pada akhirnya dilakukan pengapuran. Semua peralatan dibersihkan menggunakan disinfektan. Pemeliharaan dilakukan dari itik umur sehari (Day Old Duck/DOD) hingga itik berumur 12 minggu. Semua itik dipelihara dengan sistem dan diberikan jenis pakan yang sama. Pemberian pakan diberikan dengan cara pakan 
diletakkan di bagian tepi nampan kemudian tempat minum diletakan di tengah nampan. Jumlah pakan yang diberikan sesuai anjuran Prasetyo et al. (2010). Itik diberi pakan dan air sebanyak tiga kali sehari yaitu pagi pukul 7.00-8.00 WIB, siang pada pukul 12.00-13.00 WIB, dan sore hari pada pukul 16.00-17.00 WIB. Itik ditimbang satu minggu sekali dari minggu 0 sampai minggu ke-12.

Setelah itik mencapai umur 8, 10, dan 12 minggu, itik dipotong. Sebelum dipotong, itik dipuasakan terlebih dahulu selama 6 jam hingga 12 jam, tetapi air minum tetap diberikan ad libitum. Sesaat sebelum dipotong, itik ditimbang untuk mengetahui bobot potong, lalu itik dimasukkan ke dalam tempat pemotongan dengan posisi menggantung dan posisi kepala di bawah selama 2 menit. Pemotongan dilakukan pada perbatasan leher dan kepala, dengan memotong vena jugularis, arteri karotidea, trakea, dan esofagus. Setelah itu itik dibiarkan menggantung selama 1-1.5 menit hingga darah berhenti menetes. Itik CA kemudian dicelupkan ke dalam air panas pada suhu lebih kurang $80^{\circ} \mathrm{C}$ agar bulu mudah dicabut.

Pencabutan bulu dilakukan secara manual. Kaki, leher, dan kepala dipotong dan kemudian jeroan dikeluarkan yang terdiri dari hati, jantung, saluran pencernaan, dan limpa. Lemak abdominal juga dipisahkan dari karkas, dan selanjutnya karkas ditimbang. Karkas yang telah ditimbang kemudian dipotong hingga didapatkan bagian dada dan paha, kemudian ditimbang untuk mengetahui bobotnya. Selanjutnya dada dan paha disimpan di dalam freezer pada suhu $-18^{\circ} \mathrm{C}$.

Uji organoleptik menggunakan uji hedonik. Pengujian ini menggunakan panelis tak terlatih sebanyak 81 orang. Sampel yang diuji yaitu daging yang dipotong dengan ukuran $1 \times 1 \mathrm{~cm}$. Setiap panelis disajikan 12 sampel yang terdiri itik jantan dan betina umur 8, 10, dan 12 minggu. Panelis menuliskan hasil pengujiannya di form yang disediakan.

Peubah yang diamati dalam penelitian ini yaitu konsumsi ransum, pertambahan bobot badan, konversi ransum, bobot potong, persentase karkas, persentase dada, persentasae paha, persentase lemak abdominal, kualitas fisik karkas, dan sensori aroma daging itik.

Rancangan yang digunakan yaitu rancangan pola faktorial $(3 \times 2)$ dengan dasar rancangan acak kelompok (RAK). Faktor pertama adalah umur pemotongan dengan 3 taraf perlakuan yaitu 8, 10, dan 12 minggu. Faktor kedua yaitu jenis kelamin itik. Itik dikelompokkan berdasarkan periode penetasan. Model statistik yang digunakan yaitu:

$$
Y_{i j k}=\mu+\alpha_{i}+\beta_{j}+(\alpha \beta)_{i j}+\rho_{k}+\varepsilon_{i j k}
$$

Keterangan :

$\mathrm{Y}_{\mathrm{ijk}}=$ Nilai pengamatan pada umur pemotongan ke-I, jenis kelamin ke-j, dan kelompok ke-k $\mu \quad=$ Nilai tengah umum

$\alpha_{\mathrm{i}} \quad=$ Pengaruh umur pemotongan ke-i $(\mathrm{i}=8,10,12$ minggu)

$\beta_{\mathrm{j}} \quad=$ Pengaruh jenis kelamin ke- $\mathrm{j}(\mathrm{j}=1,2)$

$\rho_{\mathrm{k}} \quad=$ Pengaruh kelompok ke-k $(1,2,3)$

عijk = Pengaruh galat percobaan dari umur pemotongan

ke-i, jenis kelamin ke-j, dan kelompok ke-k $(1,2,3)$

$(\alpha \beta)_{\mathrm{ij}}=$ Pengaruh interaksi antara umur pemotongan ke-i dengan jenis kelamin ke-j

Data diolah dengan Analysis of Variance (ANOVA) menggunakan program statistik SAS 9.1. Jika analisis ragam menghasilkan perbedaan, maka dilanjutkan dengan uji Duncan dengan selang kepercayaan 95\% (Steel dan Torrie 1995). Hasil uji organoleptik diolah secara non parametrik menggunakan program Minitab 16. Analisis

\section{HASIL DAN PEMBAHASAN}

Hasil bobot potong itik disajikan pada Tabel 1. Hasil penelitian menunjukkan interaksi antara umur potong itik dan jenis kelamin itik CA nyata mempengaruhi bobot potong. Pada itik CA jantan, semakin tua umur potong mengakibatkan peningkatan bobot potong itik. Nilai rataan bobot potong itik CA jantan pada umur 12 minggu nyata lebih besar dibandingkan dengan umur 8 dan 10 minggu. Bobot potong itik CA pada umur 10 minggu nyata lebih besar dibandingkan pemotongan umur 8 minggu. Itik CA betina memberikan respon yang berbeda dengan itik $\mathrm{CA}$ jantan. Pada itik CA betina, bobot potong umur 10 minggu dan 12 minggu sama, tetapi keduanya nyata lebih tinggi dibandingkan dengan umur 8 minggu.

Tabel 1 juga menunjukkan bahwa pada masingmasing umur potong, bobot potong jantan nyata lebih besar dibandingkan betina. Umur pemotongan serta jenis kelamin yang berbeda berpengaruh terhadap bobot potong sejalan dengan Matitaputty et al. (2011) bahwa pertumbuhan bobot badan dipengaruhi jenis kelamin, dan umur.

Bobot potong umur 8 minggu dalam penelitian ini lebih rendah dibandingkan dengan hasil penelitian Matitaputty et al. (2011) yang mencapai bobot 1412.80 gram. Hal ini mungkin disebabkan tingkat kepadatan yang berbeda. Penelitian Matitaputty et al. (2011) menggunakan luasan $0.3 \mathrm{~m}^{2} /$ ekor, sedangkan pada penelitian ini sebesar 0.15-0.20 m²/ekor. Hasil penelitian Ali dan Febrianti (2009) menunjukkan itik dengan kepadatan kandang yang lebih tinggi memiliki pertambahan bobot badan yang lebih rendah disebabkan suhu kandang yang lebih tinggi serta tingkat stres yang lebih tinggi. Apabila suhu di sekitar ternak tinggi, maka konsumsi itik akan menurun dan diikuti penurunan pertambahan bobot badan. Berdasarkan Peraturan Menteri Pertanian (2007) daya tampung kandang itik per $\mathrm{m}^{2}$ yaitu 7 ekor $\left(0.14 \mathrm{~m}^{2} /\right.$ ekor $)$ untuk umur 5 minggu, 6 ekor $(0.16$

Tabel 1 Bobot potong itik CA pada umur pemotongan dan jenis kelamin berbeda

\begin{tabular}{lcccc}
\hline Jenis Kelamin & \multicolumn{4}{c}{ Umur potong (minggu) } \\
& 8 & 10 & 12 \\
\hline \\
Jantan & & gram & $1496.70 \pm 34.12 \mathrm{a}$ \\
Betina & $1122.58 \pm 108.58 \mathrm{~d}$ & $1354.90 \pm 40.03 \mathrm{~b}$ & $1237.00 \pm 40.94 \mathrm{c}$ \\
\hline
\end{tabular}

Keterangan : angka disertai huruf berbeda menunjukkan perbedaan nyata $(\mathrm{P}<0.05)$ 
Tabel 2 Konsumsi, PBB, dan konversi ransum itik CA

\begin{tabular}{lllccccc}
\hline \multirow{2}{*}{ Peubah } & \multicolumn{7}{c}{ Umur potong (minggu) } \\
\cline { 2 - 8 } & \multicolumn{1}{c}{ Jantan } & \multicolumn{1}{c}{ Betina } & Jantan & Betina & Jantan & Betina \\
\cline { 2 - 7 } & 4235.33 & 4179.33 & 6235.33 & 6179.33 & 8235.33 & 8179.33 \\
\hline Konsumsi (gram) & 1122.58 & 975.67 & 1354.90 & 1243.44 & 1496.70 & 1237.00 \\
PBB (gram) & 3.77 & 4.28 & 4.60 & 4.97 & 5.50 & 6.61 \\
FCR & & &
\end{tabular}

$\mathrm{m}^{2} /$ ekor $)$ untuk umur 6 minggu, dan 5 ekor $\left(0.20 \mathrm{~m}^{2} / \mathrm{ekor}\right)$ untuk umur 7 minggu.

Tabel 2 menunjukkan nilai konversi pakan (FCR) itik CA. Nilai konversi betina selalu lebih besar dibandingkan dengan jantan pada semua umur pemotongan. Hal ini disebabkan pertambahan bobot badan betina yang lebih rendah dibandingkan dengan jantan, namun konsumsinya tidak berbeda terlalu jauh. Hasil penelitian juga menunjukkan bahwa semakin tua umur potong meningkatkan nilai FCR pada masing-masing jenis kelamin. Hal ini disebabkan konsumsi yang semakin tinggi, sedangkan pertambahan bobot badan yang didapatkan semakin rendah

\section{Karkas dan Komponen Karkas}

Persentase karkas, komponen karkas, dan lemak abdominal itik CA disajikan pada Tabel 3 dan 4. Persentase bagian-bagian karkas dihitung berdasarkan bobot karkas, sedangkan persentase lemak abdominal dihitung berdasarkan bobot potong itik.

\section{Persentase Karkas}

Tabel 3 menunjukkan umur pemotongan tidak berpengaruh terhadap persentase karkas. Tabel 6 menunjukkan tidak ada perbedaan yang nyata antara persentase karkas jantan dan betina. Penelitian ini menunjukkan perbedaan jenis kelamin tidak mempengaruhi persentase karkas. Hal ini disebabkan bobot karkas mengikuti bobot potongnya, yaitu semakin tinggi bobot potong menghasilkan bobot karkas yang tinggi pula. Keragaman bobot karkas nyata dipengaruhi oleh keragaman bobot hidup (Pribady 2008). Hal ini berbeda dengan hasil penelitian Sudaryati et al. (1998) yang menunjukkan proporsi karkas itik berubah sesuai dengan pertambahan umur dan bobot hidup.

Persentase karkas yang tidak nyata ini disebabkan jarak pemotongan yang dekat. Menurut Matitaputty et al. (2011) itik CA mencapai titik infleksi pertumbuhan pada umur 3 minggu sehingga pada umur 5 minggu dan seterusnya pertumbuhan sudah berjalan lambat. Hal ini mengakibatkan

Tabel 3 Persentase komponen karkas dan lemak abdominal itik CA pada umur pemotongan berbeda

\begin{tabular}{lcrc}
\hline \multirow{2}{*}{ Peubah } & \multicolumn{3}{c}{ Umur potong (minggu) } \\
\cline { 2 - 4 } & 8 & Persentase (\%) & 12 \\
\hline Karkas & $56.55 \pm 2.39$ & $57.36 \pm 1.87$ & $56.05 \pm 0.89$ \\
Dada & $20.18 \pm 2.99 \mathrm{~b}$ & $27.17 \pm 2.91 \mathrm{a}$ & $29.91 \pm 1.09 \mathrm{a}$ \\
Paha & $31.08 \pm 1.29 \mathrm{a}$ & $25.78 \pm 0.85 \mathrm{~b}$ & $23.69 \pm 1.09 \mathrm{c}$ \\
Lemak abdominal & $0.40 \pm 0.17 \mathrm{~b}$ & $0.52 \pm 0.17 \mathrm{ab}$ & $0.60 \pm 0.15 \mathrm{a}$ \\
\hline
\end{tabular}

\section{Persentase Bagian Dada}

Bagian dada merupakan salah satu bagian yang memiliki perdagingan yang tebal. Penelitian Matitaputty et al. (2011) menunjukkan hasil persentase daging dari tulang itik CA pada bagian dada sebesar $85.55 \%$. Analisis ragam menunjukkan umur potong berpengaruh nyata terhadap persentase dada. Tabel 3 menunjukkan persentase bagian dada meningkat seiring dengan bertambahnya umur itik. Hal ini sejalan dengan penelitian Erisir et al. (2009), semakin tua umur potong itik menghasilkan persentase bagian dada yang semakin tinggi. Persentase bagian dada itik CA yang dipotong pada umur 8 minggu nyata lebih rendah dibandingkan dengan itik CA yang dipotong pada umur 10 minggu dan umur 12 minggu. Persentase karkas itik CA umur 10 minggu tidak berbeda nyata dengan itik CA umur 12 minggu. Nilai bobot dada dan persentase dada itik CA yang dipotong pada umur 10 dan 12 minggu disebabkan kecepatan pertumbuhan daging atau otot yang semakin lambat.

Pribady (2008) menyatakan pertumbuhan potongan dada tumbuh lebih lambat dibandingkan dengan pertumbuhan secara umum. Potongan bagian dada unggas adalah tempat perdagingan yang tebal dengan persentase tulang yang kecil, sehingga pada umur yang lebih muda perdagingan bagian dada masih sedikit dan akan meningkat seiring dengan umur yang meningkat. Persentase bagian dada akan meningkat ketika pertumbuhan tulang menurun dan pertumbuhan otot meningkat. Persentase dada yang tidak berbeda antara jantan dan betina terjadi karena kecepatan pertumbuhan daging yang sama pada keduanya. Penelitian Erisir et al. (2009) menunjukkan hingga umur 9 minggu tidak ada perbedaan antara karkas itik jantan dan betina.

\section{Persentase Bagian Paha}

Tempat deposit daging pada karkas itik yang paling banyak selain bagian dada yaitu bagian paha. Persentase tulangnya hanya sebesar $14.27 \%$ (Matitaputty et al. 2011). daging itik CA pada bagian paha sebesar $85.73 \%$ dan

Keterangan : angka disertai huruf berbeda pada baris yang sama menunjukkan perbedaan nyata $(\mathrm{P}<0.05)$ 
Tabel 4 Persentase komponen karkas dan lemak abdominal itik CA pada jenis kelamin berbeda

\begin{tabular}{lcc}
\hline \multirow{2}{*}{ Peubah } & \multicolumn{2}{c}{ Jenis kelamin } \\
\cline { 2 - 3 } & \multicolumn{1}{c}{ Persentase (\%) } \\
Karkas & $56.95 \pm 1.79$ & $56.35 \pm 1.86$ \\
Dada & $25.38 \pm 5.16$ & $26.12 \pm 4.74$ \\
Paha & $26.85 \pm 3.24$ & $26.85 \pm 3.68$ \\
Lemak abdominal & $0.49 \pm 0.19$ & $0.52 \pm 0.17$ \\
\hline Bagian paha terdiri dari 2 bagian, yaitu paha atas dan paha & $\begin{array}{c}\text { yang cepat dan itik masih mengalami fase pertumbuhan } \\
\text { bawah. Analisis ragam menunjukkan umur pemotongan }\end{array}$ & daging hingga umur 12 minggu.
\end{tabular}

berpengaruh nyata terhadap persentase paha itik CA. Semakin tinggi umur potong mengakibatkan semakin rendahnya persentase bagian paha. Hasil ini sesuai dengan hasil penelitian Erisir et al. (2009), semakin tua umur itik akan menurunkan persentase bagian paha terhadap bobot karkas. Persentase paha itik CA yang dipotong pada umur 8 minggu nyata lebih besar dibandingkan umur 10 dan 12 minggu. Persentase paha itik umur 10 minggu nyata lebih besar dibandingkan dengan umur 12 minggu (Tabel 3). Persentase paha tidak dipengaruhi oleh jenis kelamin (Tabel 4), sesuai dengan pendapat Erisir et al. (2009) bahwa persentase karkas dan bagian-bagiannya tidak berbeda antara jantan dan betina hingga umur 9 minggu.

Berbeda dengan bagian dada, seiring dengan bertambahnya umur (hingga 12 minggu) persentase bagian paha semakin rendah. Hal ini dapat terjadi karena bagian paha tumbuh lebih dulu dibandingkan dengan pertumbuhan bagian dada dan pertumbuhan secara umum. Ketika bagian dada dan pertumbuhan bagian lain semakin tinggi dan cepat, bagian paha hanya mengalami sedikit peningkatan dan persentasinya terhadap bobot karkas semakin kecil. Persentase potongan paha akan menurun dengan menurunnya pertumbuhan tulang dan meningkatnya pertumbuhan otot (Pribady 2008).

\section{Presentase Lemak Abdominal}

Lemak abdominal adalah lemak yang berada di sekeliling rempela dan yang terdapat di dalam rongga perut dan usus (Kubena et al. 1974). Peningkatan lemak abdominal tidak dapat dipisahkan dari peningkatan bobot badan unggas. Kadar protein pakan memberikan pengaruh nyata terhadap persentase lemak abdomen terhadap bobot hidup atau bobot karkas.

Persentase lemak abdominal itik CA dipengaruhi oleh umur potong (Tabel 3). Persentase lemak abdominal itik CA yang dipotong pada umur 8 minggu nyata lebih rendah dibandingkan umur potong 12 minggu namun tidak berbeda nyata dengan umur 10 minggu. Hal ini menunjukkan semakin tua umur itik CA, semakin meningkat pula jumlah dan persentase lemaknya. Fuller (2004) menyatakan bahwa pertumbuhan jaringan dimulai dari pertumbuhan tulang, otot, dan terakhir lemak.

Persentase lemak abdominal tidak berbeda antara itik CA jantan dan betina (Tabel 4). Hasil ini berbeda dengan pendapat Bell dan Weaver (2002) yang menyatakan persentase lemak abdomen betina lebih tinggi dibandingkan dengan jantan. Hal ini disebabkan oleh pertumbuhan lemak pada itik CA jantan dan betina belum pada fase perlemakan

\section{Kualitas Karkas}

Kualitas fisik karkas sangat mempengaruhi penerimaan konsumen terhadap daging itik. Konsumen umumnya lebih menyukai karkas itik yang segar dan bersih dibandingkan dengan karkas yang sudah pucat dan kotor. Salah satu hal yang menyebabkan karkas terlihat tidak bersih, yaitu adanya bulu-bulu jarum pada kulit di seluruh bagian karkas.

Berdasarkan USDA (1998) dalam Poultry-Grading Manual, karkas atau bagian-bagian karkas harus memiliki penampilan yang bersih, terlebih pada bagian dada dan paha, dan bebas dari bulu-bulu yang menonjol atau tertinggal pada karkas. Gambar 1 menunjukkan penampilan bagian punggung karkas itik CA hasil penelitian ini.

Gambar 1 memperlihatkan bahwa pada karkas itik jantan 8 minggu (a) terlihat lebih banyak bulu-bulu jarum dibandingkan dengan karkas itik jantan umur 10 (b) dan 12 minggu (c). Punggung itik jantan umur 12 minggu terlihat bersih dan hanya sedikit terdapat bulu jarum. Sama halnya dengan itik jantan, karkas itik betina umur 12 minggu (f) terlihat lebih bersih dibandingkan dengan karkas itik betina umur 8 (d) dan 10 minggu (e). Perbedaan banyaknya bulu jarum pada karkas ini disebabkan periode pertumbuhan bulu itik. Pada umur 8 minggu, itik masih mengalami pertumbuhan bulu yang pesat, sehingga banyak bakal bulu yang terlihat dibawah kulit setelah itik dijadikan karkas. Semakin tua umur itik, bakal bulu tersebut semakin hilang karena sudah tumbuh menjadi bulu tetap.

Gambar 2 menunjukkan penampilan karkas itik CA bagian abdomen. Apabila dibandingkan dengan bagian punggung, bagian dada lebih bersih dari bulu-bulu jarum. Hal ini disebabkan kecepatan tumbuh bulu yang berbeda

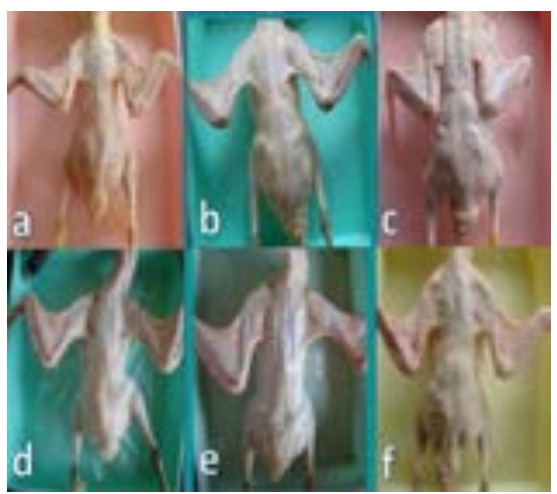

Gambar 1. Penampilan karkas bagian punggung itik CA (a) jantan 8 minggu, (b) jantan 10 minggu (c) jantan 12 minggu (d) betina 8 minggu, (e) betina 10 minggu, (f) betina 12 minggu 


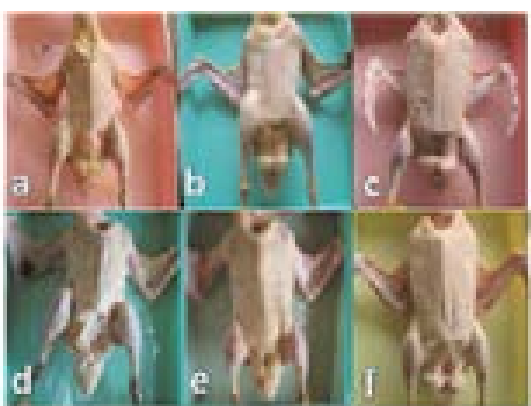

Gambar 2. Penampilan karkas bagian abdomen itik CA (a) jantan 8 minggu, (b) jantan 10 minggu (c) jantan 12 minggu (d) betina 8 minggu, (e) betina 10 minggu, (f) betina 12 minggu

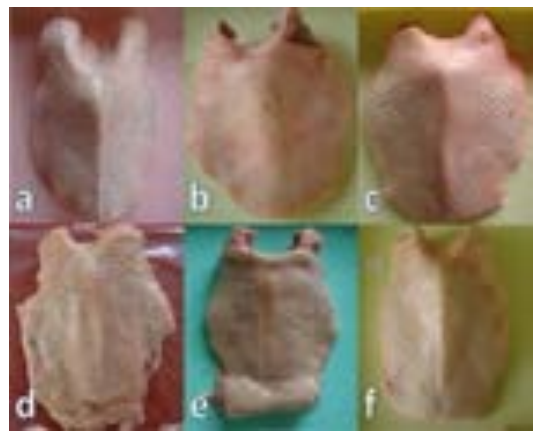

Gambar 3.Penampilan karkas bagian dada itik CA (a) jantan 8 minggu, (b) jantan 10 minggu (c) jantan 12 minggu (d) betina 8 minggu, (e) betina 10 minggu, (f) betina 12 minggu

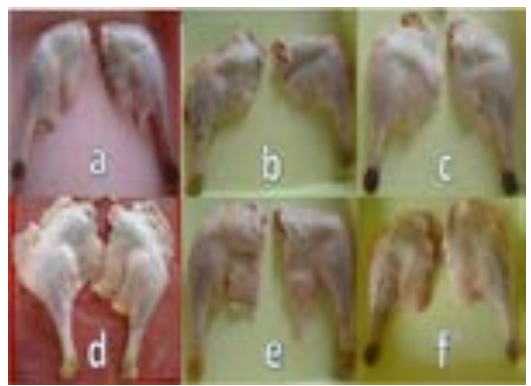

Gambar 4. Penampilan karkas bagian paha itik CA (a) jantan 8 minggu, (b) jantan 10 minggu (c) jantan 12 minggu (d) betina 8 minggu, (e) betina 10 minggu, (f) betina 12 minggu

pada tiap bagian tubuh. Bulu bagian dada tumbuh lebih cepat dibandingkan bagian punggung ataupun bagian yang lain, sehingga pada umur potong $(8,10$, dan 12 minggu) hanya sedikit bakal bulu yang tersisa. Cherry dan Morris (2008) menjelaskan bahwa bulu pada bagian dada mulai tumbuh pada umur 14 hari dan telah tumbuh sepenuhnya pada umur 35 hari, sedangkan bulu pada punggung mulai tumbuh pada umur 30 hari dan tumbuh sepenuhnya pada umur 50-60 hari.

Gambar 3 dan 4 menunjukkan bagian dada dan paha itik CA pada berbagai umur dan jenis kelamin. Bagian ini memperlihatkan bahwa semakin tinggi umur itik CA maka karkasnya semakin bersih dari bulu-bulu jarum. Selain itu, karkas itik umur 12 minggu lebih mudah dibersihkan bulu jarumnya dibandingkan dengan umur 10 dan 8 minggu. Bagian dada dan paha adalah bagian yang paling banyak deposit daging dibandingkan dengan bagian karkas lainnya. Selain itu bagian paha dan dada adalah bagian yang paling banyak dikonsumsi maka penampilan bagian dada dan paha akan sangat mempengaruhi penerimaan konsumen. Gambar 1, 2, 3, dan 4 menunjukkan bulu-bulu jarum pada bagian karkas jantan lebih sedikit dibandingkan pada betina. Selain itu, karkas itik CA jantan lebih mudah dibersihkan dari bulu jarum dibandingkan betina. Hal ini disebabkan oleh kecepatan pertumbuhan bulu jantan dan betina berbeda. Produksi bulu membutuhkan banyak nutrisi dan energi (Stettenheim 2000). Tabel 2 menunjukkan konsumsi itik jantan lebih tinggi dari betina, maka nutrisi yang digunakan untuk pertumbuhan bulu juga lebih banyak, sehingga pertumbuhan bulu itik jantan lebih cepat dibandingkan betina.

\section{Analisis Sensori Daging Itik}

Analisis sensori daging adalah suatu proses identifikasi, pengukuran ilmiah, analisis, dan interpretasi atribut-atribut produk melalui pancaindra manusia. Analisis sensori melibatkan suatu pengukuran yang dapat bersifat kualitatif maupun kuantitatif (Setyaningsih et al. 2010). Winarno (2008) menjelaskan bahwa citarasa pangan sesungguhnya terdiri dari tiga komponen yaitu bau, rasa, dan rangsangan mulut. Bau yang diterima oleh hidung dan otak umumnya merupakan campuran empat bau utama yaitu harum, asam, tengik, dan hangus Winarno (2008). Uji hedonik aroma daging itik CA pada umur pemotongan dan jenis kelamin berbeda disajikan dalam Tabel 5 .

Umur pemotongan 8, 10, dan 12 minggu tidak mempengaruhi tingkat kesukaan konsumen terhadap daging itik CA jantan dan betina (Tabel 5). Tingkat kesukaan panelis terhadap daging itik jantan maupun betina berkisar antara 3.51-3.84 yang menunjukkan bahwa panelis agak menyukai aroma daging. Tidak adanya perbedaan tingkat kesukaan panelis ini dapat disebabkan aroma daging yang hampir sama. Aroma daging dipengaruhi oleh komponen volatil. Komponen volatil inilah yang kemudian memberikan sensasi bau melalui reseptor pada hidung dan menguap dengan cepat (Winarno 2008). Hamilton (1983) menjelaskan penurunan kualitas daging umumnya disebabkan perubahan komponen lemak melalui proses oksidasi lemak atau reaksi hidrolisis.

Tabel 5 juga menunjukkan hasil jenis kelamin itik yang berbeda tidak mempengaruhi tingkat kesukaan konsumen terhadap daging itik CA pada masing-masing umur pemotongan. Panelis memberikan tanggapan agak

Tabel 5 Nilai tingkat kesukaan (hedonik) aroma daging itik CA pada umur pemotongan berbeda

\begin{tabular}{llcc}
\hline Jenis kelamin & \multicolumn{3}{c}{ Umur potong (minggu) } \\
\cline { 2 - 4 } & \multicolumn{1}{c}{8} & 10 & 12 \\
\hline & Nilai tingkat kesukaan (Hedonik) & & $3.84 \pm 0.84$ \\
Jantan & $3.69 \pm 0.87$ & $3.51 \pm 0.86$ & $3.82 \pm 0.86$ \\
Betina & $3.58 \pm 0.92$ & $3.67 \pm 0.81$ & \\
\hline
\end{tabular}

Keterangan : Nilai yang lebih besar menunjukkan tingkat kesukaan yang lebih baik 
suka. Tingkat kesukaan konsumen yang tidak berbeda antar umur pemotongan dan jenis kelamin diperkirakan dapat disebabkan kandungan lemak daging yang tidak jauh berbeda. Secara hormonal, produksi lemak dipengaruhi oleh hormon estrogen (Velle 1981). Pada umur 8 hingga 12 minggu, itik belum memasuki periode masak kelamin sehingga kadar estrogen yang dihasilkan tidak berbeda nyata dan produksi lemak pada kedua jenis kelamin tidak berbeda signifikan. Berdasarkan hasil penelitian Penghasil utama hormone estrogen adalah ovarium. Selain di ovarium, estrogen juga dihasilkan oleh adrenal korteks dan testis tetapi dalam jumlah yang tidak banyak (Lehninger 1982). Roesdiyanto (2004) umur dewasa kelamin itik lokal dicapai pada umur 5.5 bulan.

\section{KESIMPULAN}

Perbedaan umur potong mempengaruhi bagian-bagian karkas, lemak abdominal, dan kualitas penampilan karkas, namun perbedaan jenis kelamin hanya mempengaruhi persentase bobot potong serta penampilan karkas itik. Itik yang dipelihara lebih lama (10 dan 12 minggu) menunjukkan hasil yang lebih baik dari segi persentase bagian karkas dan lemak, serta kualitas penampilan karkasnya.

\section{DAFTAR PUSTAKA}

Ali A, Febrianti N. 2009. Performans itik pedaging (lokal $\mathrm{x}$ Peking) fase starter pada tingkat kepadatan kandang yang berbeda di desa Laboi Jaya Kabupaten Kampar. $J$ Petern Vol 6: 29-35.

Bell DD, Weaver WD. 2002. Commercial Chicken Meet and Egg Production. Ed ke-5. New York (US): Springer.

Badan Standardisasi Nasional. 2009. Mutu Karkas dan Daging Ayam. SNI 3924:2009. Jakarta (ID): Badan Standardisasi Nasional.

Cherry P, Morris TR. 2008. Domestic Duck Production Science and Practice. Cambridge (US): CABI Publishings.

Direktorat Jenderal Peternakan. 2012. Buku Statistik Peternakan. Jakarta (ID): Dirjen Bina Produksi Peternakan. Departemen Pertanian

Erisir Z, Poyraz O, Onbasilar EE, Erdem E, Oksuztepe GA. 2009. Effects of housing system, swimming pool and slaughter age on duck performance, carcass and meat characteristics. J Anim Vet Adv 8(9): 1864-1869.
Fuller MF. 2004. The Encyclopedia of Farm Animal Nutrition. Cambridge (US): CABI Publishings.

Hamilton RJ. 1983. The Chemistry of Rancidity in Foods. In: Rancidity in Foods. Allen JC, Hamilton RJ, editor. New York (US): Applied Science Publishers.

Kubena, Deaton LFW, Chen TC, Recee FN. 1974. Factor influencing the quantity of abdominal fat in broiler. Poult Sci. 53: 211-214.

Lehninger AL. 1982. Dasar-Dasar Biokimia. Thenawidjaya M, penerjemah. Jakarta (ID): Erlangga. Terjemahan dari: Principle of Biochemistry.

Matitaputty PR, Noor RR, Hardjosworo PS, dan Wijaya CH. 2011. Performa, persentase karkas dan nilai heterosis itik Alabio, Cihateup dan hasil persilangannya pada umur delapan minggu. JITV 16(2): 90-97.

North MO, Bell DD. 1990. Commercial Chicken Production Manual. London (GB): Chapman and Hall.

Peraturan Menteri Pertanian. 2007. Pedoman Budidaya Itik yang Baik. Jakarta: Kementerian Pertanian

Prasetyo LH, Ketaren PP, Setioko AR, Suparyanto A, Juwarini E, Susanti T, Sopiyana S. 2010. Panduan Budidaya dan Usaha Ternak Itik. Bogor (ID): Balai Penelitian Ternak.

Pribady WA. 2008. Produksi karkas angsa (Anser cygnoides) pada berbagai umur pemotongan. [skripsi]. Bogor (ID): Institut Pertanian Bogor.

Roesdiyanto. 2004. Substitusi tepung ikan dengan udang pengko (Squilla empusa) dalam pakan terhadap kinerja reproduksi itik lokal. Animal Production 6(2): 110117.

Setyaningsih D, Apriyantono A, Sari MP. 2010. Analisis Sensori untuk Industri Pangan dan Agro. Bogor (ID): IPB Pr.

Steel RG, Torrie JH. 1995. Principles and Procedures of Statistics: A Biometerial Approach. Ed ke-2. New York (US): Mc Graw-Hill.

Stettenheim PR. 2000. The integumentary morphology of modern birds-an overview. American Zoologist. 40:461-477. New York (US): Oxford University Pr.

Sudaryati S, Sasongko H, Harimurti S. 1998. Relationship of sex, age, and body weight to local duck carcass yield. Bul Peter. Yogyakarta (ID): Universitas Gadjah Mada.

[USDA]. 1998. Poultry-Grading Manual. Washington DC (US): United States Department of Agriculture

Velle W. 1981. Hormones in Animal Production. FAO Animal Production and Health Paper. Rome (IT): Food and Agriculture Organization.

Winarno FG. 2008. Kimia Pangan dan Gizi Edisi 1. Bogor (ID): M-Brio Pr. 